\title{
THE EFFECT OF pH ON BIOSURFACTANT PRODUCTION BY BACILLUS SUBTILIS DSM10
}

\author{
RÉKA CZINKócZKYY1 AND Áron NÉmetH *1 \\ ${ }^{1}$ Department of Applied Biotechnology and Food Science, Budapest University of Technology and \\ Economics, Múegyetem rkp. 3, Budapest, 1111, HUNGARY
}

\begin{abstract}
The genus Bacillus has long been known for its ability to produce many industrially useful products. These bacteria mostly produce extracellular products like organic acids, enzymes and biosurfactants. In this paper, the production of surfactin using the Bacillus subtilis strain DSM10 is investigated. Biosurfactant was produced in a lab-scale 1-liter fermenter. $\mathrm{pH}$ control using different bases $\left(\mathrm{NH}_{4} \mathrm{OH}\right.$ and $\left.\mathrm{NaOH}\right)$ was compared to observe whether the amount of produced biosurfactant or the quality of the product was influenced. The formation of the product was followed by measuring the surface tension, and the product formed was analyzed by reversed-phase chromatography. The investigation of the effect of $\mathrm{pH}$ control showed that it can be omitted during the fermentation of the biosurfactant. The highest concentration of surfactin $(5 \mathrm{~g} / \mathrm{L})$ was achieved without $\mathrm{pH}$ control in contrast with when the $\mathrm{pH}$ was kept constant $(\mathrm{pH}=7)$.
\end{abstract}

Keywords: biosurfactant, surfactin, fermentation, purification, Bacillus subtilis

\section{Introduction}

In recent years, the microbial production of tensio-active molecules with various properties, e.g. emulsifying, wetting, foaming, detergency, solubilizing and dispersing, has been gaining interest [1]. Biosurfactants are amphiphilic compounds produced by a variety of microbial communities. Natural surfactants are of great importance in the pharmaceutical, cosmetic, agricultural and food industries due to their beneficial properties including low toxicity, biodegradability, high selectivity and activity under extreme environmental conditions [2,3]. The market of bio-based surfactants is predicted to be worth $\$ 5.52$ billion by 2022 [4]. This is unsurprising given our high degree of dependency on kinds of hygiene products, the majority of which include surfactants or emulsifiers.

Biosurfactants are classified based on their chemical structure into the following groups: glycolipids, lipopeptides, fatty acids and lipids, as well as polymeric and particulate biosurfactants $[3,5]$. One of the most effective biosurfactants is surfactin. This lipopeptide-type surfactant contains a cyclic peptide linked to a fatty acid chain (Fig. 1) [6]. Bóka et al. reported that the molecular weights of surfactins range from $993 \mathrm{Da}$ to 1049 Da [7]. Several gram-positive Bacillus species naturally produce surfactins, which help the bacteria to stabilize their cell membranes and adhere to a surface $[8,9]$. The biosynthesis of surfactin occurs through different mechanisms: the conversion of glucose or glycerol as a substrate

\footnotetext{
*Correspondence: naron@f-labor.mkt.bme.hu
}

to glucose 6-phosphate through the glycolytic pathway, providing the main precursor of carbohydrates located in the hydrophilic part and the oxidation of glucose to pyruvate then to acetyl-CoA, which serves as a precursor for the synthesis of lipids and amino acids (Asp, Glu, Leu, Val). However, if the substrate is a hydrocarbon, the metabolism is shifted towards the lipolytic pathway ( $\beta$ oxidation into acetyl-CoA) and gluconeogenesis (acetyl$\mathrm{CoA}$ involved in the synthesis of the precursor glucose 6-phosphate) [1].

The effectiveness of surfactants is defined by their ability to reduce the surface tension (ST), defined as the cohesive force between molecules which is proportional to the concentration of surfactant in the solution [2]. Their efficiency is measured by the critical micelle concentration (CMC) [1,11]. Above the CMC, surfactants form micellar structures, but below it, the aggregates dissociate into monomers. Lipopeptides from B. subtilis are particularly compelling because their surface activity has been reported to be strong $[6,12,13]$. Powerful surfactants can decrease the surface tension of water $\left(72 \mathrm{mN} / \mathrm{m}\right.$ at $\left.20^{\circ} \mathrm{C}\right)$ to less than $30 \mathrm{mN} / \mathrm{m}$ [14]. The emulsifying capacity can be monitored by calculating the emulsification index (EI, $\%$ ) and emulsion stability. As the $\mathrm{pH}$ decreases, surfactin becomes less soluble in water because the carboxyl group is protonated [12]. Under neutral or basic conditions, the carboxyl group is in the ionic form, thus its solubility and emulsification capability increases [15]. Moro et al. evaluated the influence of the $\mathrm{pH}$ on the stability of the surfactants produced by species of B. subtilis, B. gibsonii and $B$. 


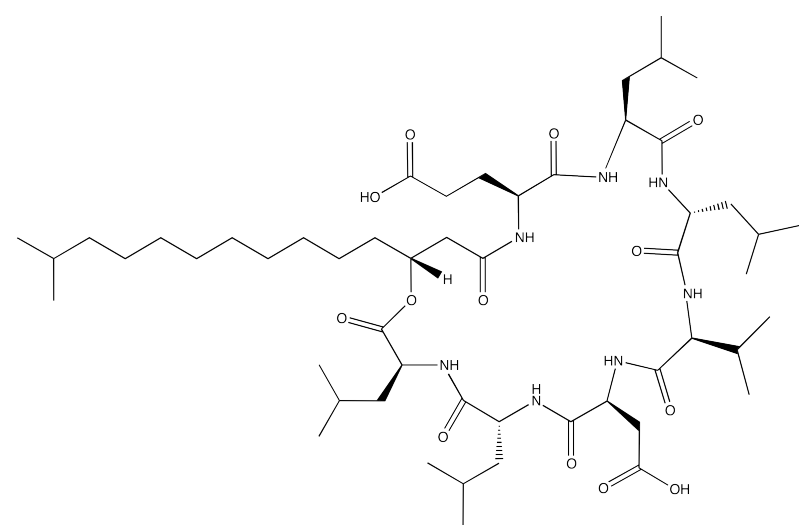

Figure 1: Chemical structure of surfactin: peptide loop of amino acids: five L-amino acids (Val, Asp, Leu, Glu and Leu) two D-amino acids (Leu and Leu), and a $\alpha, \beta$ hydroxy C13-C15 fatty acid chain [10]

amyloliquefaciens [9]. All isolates exhibited surface tensions below $30 \mathrm{mN} / \mathrm{m}$. In strongly acidic conditions, the emulsifying activity significantly decreased for both $B$. subtilis ODWO2 and B. subtilis ODW15. As the $\mathrm{pH}$ was increased from 7 to 12 , the stability of the surfactant produced by B. subtilis ODWO2 decreased even further, but the one by $B$. subtilis $O D W 15$ remained stable. In the case of B. amyloliquefaciens MO13, a significant increase was observed both under acidic and basic conditions. This different $\mathrm{pH}$-responsive behavior makes surfactin applicable in a variety of industrial fields.

The choice of fermentation cultivation media (i.e. of average composition, carbon source, nitrogen source and trace elements) as well as fermentation strategies (i.e. temperature, $\mathrm{pH}$, aeration and agitation) also need to be considered in relation to the type of applications. Based on a literature review, the best combination among the fermentation conditions was $1.5 \mathrm{vvm}$ at $300 \mathrm{rpm}$, resulting in a maximum yield of surfactin of $6.45 \mathrm{~g} / \mathrm{L}$ [16]. $B$. subtilis ATCC 21332 was grown on an iron-enriched minimal salt (MSI) medium including glucose (40 g/L). In a recent study, Yang et al. used nanoparticles (NPs) to improve the total yield of surfactin. $5 \mathrm{~g} / \mathrm{L}$ of Fe NPs were added to the fermentation medium of $B$. amyloliquefaciens MT45, which increased the titer of surfactin from 5.94 to $9.18 \mathrm{~g} / \mathrm{L}$. Modifying the biosynthesis of surfactin with metabolic engineering tools can further increase production and titers of surfactin in B. subtilis, as demonstrated by $\mathrm{Wu}$ et al. (12.8 g/L) [17]. Few studies have focused on individual characteristics and relative amounts of surfactin variants in the extracts of lipopeptides. Many surfactin variants exist with various lengths of fatty acid chains and different amino acid sequences [5]. Akpa et al. analyzed the replacement of L-glutamic acid with four other amino acids, namely L-leucine, L-valine, Lisoleucine and L-threonine, in the culture medium. The presence of Thr was found to be favorable for the synthesis of longer (C15-C16) fatty acid chains in B. subtilis $S 499$ [18]. Supplementation with $\mathrm{Mn}^{2+}, \mathrm{Cu}^{2+}$ and $\mathrm{Ni}^{2+}$ ions can also promote the production of novel variants of surfactin with different components of fatty acids (C16C18) and amino acids (central aspartic acid methyl ester residue instead of aspartate) [19]. This approach can be useful for studying specific biological activities.

The objectives of our study were to explore the effect of $\mathrm{pH}$ control on the production of biosurfactants (i.e. on titers and productivity) by the B. subtilis strain DSM1O and evaluate the properties of biosurfactants, i.e. type, surface tension reduction and emulsifying activity.

\section{Materials and methods}

\subsection{Cultivation conditions}

Bacillus subtilis DSM10 (NCAIM B.02624T) was used for biosurfactant fermentation in this study. Cultivation was performed at $37^{\circ} \mathrm{C}$ in $250 \mathrm{ml}$ Erlenmeyer flasks containing $100 \mathrm{ml}$ of an inorganic medium based on the composition used by Joshi et al. (2013): 34 g glucose, $1.0 \mathrm{~g} \mathrm{NH}_{4} \mathrm{NO}_{3}, 6.0 \mathrm{~g} \mathrm{KH}_{2} \mathrm{PO}_{4}, 2.7 \mathrm{~g} \mathrm{Na}_{2} \mathrm{HPO}_{4}, 0.1 \mathrm{~g}$ $\mathrm{MgSO}_{4} \bullet 7 \mathrm{H}_{2} \mathrm{O}, 1.2 \cdot 10^{-3} \mathrm{~g} \mathrm{CaCl}_{2} \bullet 2 \mathrm{H}_{2} \mathrm{O}, 1.65 \cdot 10^{-3} \mathrm{~g}$ $\mathrm{FeSO}_{4} \bullet 7 \mathrm{H}_{2} \mathrm{O}, 1.5 \cdot 10^{-3} \mathrm{~g} \mathrm{MnSO}_{4} \bullet 4 \mathrm{H}_{2} \mathrm{O}$ and $2.2 \cdot 10^{-3}$ g Na-EDTA [20].

The experiments were carried out in a $1 \mathrm{~L}$ benchtop bioreactor, with a working volume of $0.8 \mathrm{~L}$ (Biostat Q fermenter, B. Braun Biotech International, Germany) and a $10 \% \mathrm{v} / \mathrm{v}$ inoculum. For biosurfactant production, the temperature was adjusted to $37^{\circ} \mathrm{C}$ with an agitation speed of $300 \mathrm{rpm}$ and an aeration rate of 0.25 vvm. The $\mathrm{pH}$ was controlled by $25 \% \mathrm{H}_{2} \mathrm{SO}_{4}$ and two different bases, namely $25 \% \mathrm{NH}_{4} \mathrm{OH}$ and $25 \% \mathrm{NaOH}$. Biosurfactant fermentation without external $\mathrm{pH}$ control served as a controlled experiment. A cyclone separator for reducing foam was connected to the outlet airstream of the fermenter (Fig. 2). The foam could overflow from the fermenter via the air outlet, through the cyclone separator to the collector flask.

\subsection{Analysis of biomass}

Bacterial growth was monitored by measuring the optical density of the fermentation broth at $600 \mathrm{~nm}$ using a Pharmacia LKB Ultrospec Plus spectrophotometer in comparison with that of the centrifuged supernatant of the sample.

The biomass concentration ( $\mathrm{g}$ cell dry weight/L) was determined by using a calibration curve $\left(R^{2}=1\right)$ :

$$
\text { Biomass }[\mathrm{g} / \mathrm{L}]=0.4283 \cdot \mathrm{OD}_{600}+1.4568
$$

The sampled broth was centrifuged at $6,000 \mathrm{rpm}$ for 15 mins. The cell pellets were collected and dried at $105^{\circ} \mathrm{C}$ to constant weight by a Sartorius MA35 moisture analyzer to measure the cell dry weight. 


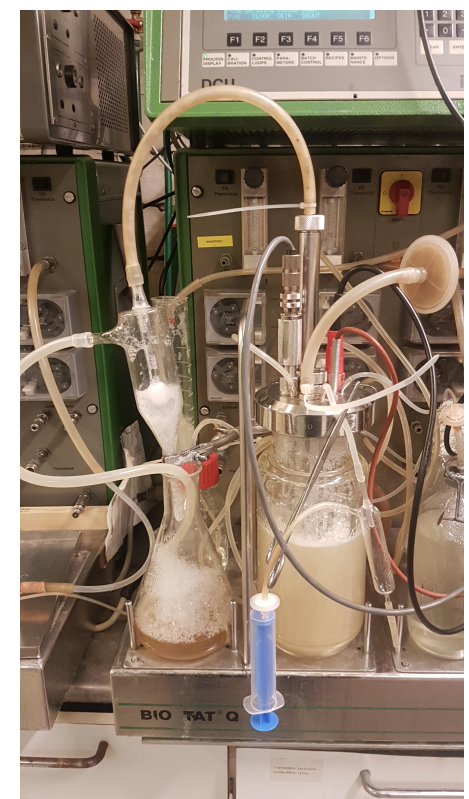

Figure 2: Fermentation setup with foam-separating glass cyclone

\subsection{Analysis of glucose consumption}

Glucose consumption was determined using the Waters Breeze 2 HPLC System. The mobile phase was $5 \mathrm{mM}$ $\mathrm{H}_{2} \mathrm{SO}_{4}$ and the rate of elution was $0.5 \mathrm{~mL} / \mathrm{min}$. A BIORAD Aminex HPX-87H $(300 \times 7.8 \mathrm{~mm}, 9 \mu \mathrm{m})$ column $\left(65^{\circ} \mathrm{C}\right)$ was applied with a Refractive Index detector $\left(40^{\circ} \mathrm{C}\right)$.

The glucose concentration was calculated from the peak area by the following calibration curve equation $\left(R^{2}=1\right)$ :

$$
\text { Glucose }[\mathrm{g} / \mathrm{L}]=4 \cdot 10^{-6} \cdot \text { PeakArea }+0.0147
$$

\subsection{Analysis of biosurfactants}

\section{Surface tension measurement}

The surface activities of biosurfactants produced by the bacterial strains were determined by measuring the surface tension of the samples of cell-free broth using the stalagmometric method with a Traube Stalagmometer (2.5 mL, Wilmad-LabGlass LG-5050-102 Stalagmometer Tube for samples of low viscosity) at room temperature $\left(25^{\circ} \mathrm{C}\right)$. To increase the accuracy of the surface tension measurements, the averages of triplicates were used in this report. The surface tension can be determined based on the number of drops that fall per unit volume, the density of the sample and the surface tension of a liquid reference, e.g. deionized water.

The actual number of drops was calculated using

$$
N=N_{0}+\frac{x-y}{c}
$$

where $N$ denotes the number of drops of the sample calculated to the nearest tenth of a drop; $N_{0}$ represents an integer of drops counted between capillary-scale readings $x$ and $y ; x$ and $y$ stand for capillary-scale readings based on the maximum data point as 0 and the minimum data point as $40 ; x$ and $y$ refer to the distances in millimeters from the beginning of each scale; and $c$ is the capillary-scale calibration in millimeters per drop.

The surface tension (ST in $\mathrm{mN} / \mathrm{m}$ ) was calculated according to

$$
\mathrm{ST}=\frac{\mathrm{ST}_{\mathrm{w}} \cdot N_{\mathrm{w}} \cdot D}{N \cdot D_{\mathrm{w}}}
$$

where $\mathrm{ST}_{\mathrm{w}}$ denotes the surface tension of water at $25^{\circ} \mathrm{C}$ (72 mN/m); $N_{\mathrm{w}}$ represents the number of water drops (20 drops); $D$ stands for the density of the sample in $\mathrm{g} / \mathrm{mL}$; $N$ refers to the number of drops of sample, and $D_{\mathrm{w}}$ is the density of water at $25^{\circ} \mathrm{C}$.

\section{Emulsifying activity}

The emulsifying activity was determined by the addition of $2 \mathrm{~mL}$ of sunflower oil to the same volume of cellfree sample or surfactin solution in a test tube, which was vortex-mixed vigorously for 2 mins. [21]. The tubes were incubated at $25^{\circ} \mathrm{C}$ and the emulsification index (EI) determined after 24 hours according to:

$$
\mathrm{EI}_{t}=\left(\frac{H_{\mathrm{e}}}{H_{\mathrm{t}}}\right) 100
$$

where $H_{\mathrm{e}}$ and $H_{\mathrm{t}}$ are the height of emulsion and total height of the liquid in the tube, respectively.

To study the emulsion stability, the same protocol was used. The emulsification index (EI, \%) was determined after $1 \mathrm{~h}$ and the EI measured after $24 \mathrm{~h}\left(\mathrm{EI}_{24}, \%\right)$, the tubes were incubated at $25^{\circ} \mathrm{C}$. The emulsion stability was expressed as a function of the changes in EI over the 24 h.

\section{High-performance liquid chromatography (HPLC)}

The surfactin concentration was measured by HPLC using a Waters Alliance 2695 Separations Module, which is a high-performance liquid chromatographic system equipped with a Waters 2996 photodiode array detector, at $205 \mathrm{~nm}$ and a Symmetry C18 Column $(4.6 \times 150 \mathrm{~mm}$, $5 \mu \mathrm{m}$ - Waters, Ireland). The mobile phase consisted of $20 \% \mathrm{v} / \mathrm{v}$ trifluoroacetic acid (TFA) $(3.8 \mathrm{mM})$ and $80 \%$ $\mathrm{v} / \mathrm{v}$ acetonitrile. The elution rate was $1 \mathrm{~mL} / \mathrm{min}$ at $25^{\circ} \mathrm{C}$ and the sample volume was $10 \mu \mathrm{L}$. The purified surfactin was identified by using commercially available surfactin (Wako Chemicals) as the authentic compound [22].

\subsection{Isolation of the biosurfactant}

The method for purifying the biosurfactant was adapted from the one outlined by Joshi et al. (2008) [23]. The cell-free broth was obtained by centrifuging the fermentation broth at $4,000 \mathrm{rpm}$ for 20 mins. at $4^{\circ} \mathrm{C}$ using a Janetzki MLW K23D centrifuge. The cell-free broth was used for further purification steps. The biosurfactant was recovered from the supernatant by acid precipitation: the 
Table 1: Summary of the results of the fermentations

\begin{tabular}{llll}
\hline & without $\mathrm{pH}$ control & $25 \% \mathrm{NH}_{4} \mathrm{OH}$ & $25 \% \mathrm{NaOH}$ \\
\hline Biomass yield $[\mathrm{g} / \mathrm{g}]$ & $0.06 \pm 0.02$ & $0.06 \pm 0.02$ & 0.08 \\
Biosurfactant yield $[\mathrm{g} / \mathrm{g}]$ & $0.120 \pm 0.04$ & $0.073 \pm 0.07$ & 0.123 \\
Glucose conversion $[\%]$ & $78.90 \pm 22$ & $71.40 \pm 4$ & 58.35 \\
Final biosurfactant concentration $[\mathrm{g} / \mathrm{L}]$ & $3.36 \pm 2.3$ & $2.00 \pm 1.5$ & 2.34 \\
Minimum surface tension $[\mathrm{mN} / \mathrm{m}]$ & $51.1 \pm 1$ & $54.3 \pm 17$ & 68.4 \\
Biomass productivity $[\mathrm{g} / \mathrm{l} \cdot \mathrm{h}]$ & $0.060 \pm 0.03$ & $0.089 \pm 0.05$ & 0.064 \\
Biosurfactant productivity $[\mathrm{g} / \mathrm{l} \cdot \mathrm{h}]$ & $0.100 \pm 0.05$ & $0.034 \pm 0.02$ & 0.064 \\
\hline
\end{tabular}

$\mathrm{pH}$ was adjusted to 2.0 using $6 \mathrm{~N} \mathrm{HCl}$ and kept at $4{ }^{\circ} \mathrm{C}$ overnight. The precipitate was collected by centrifugation at $4,000 \mathrm{rpm}$ for 20 mins. at $4^{\circ} \mathrm{C}$, then resuspended in distilled water. The $\mathrm{pH}$ was adjusted to 7.0 using $6 \mathrm{~N}$ $\mathrm{NaOH}$ and the solution lyophilized by a Christ Alpha 2-4 LSC freeze dryer. The concentration of biosurfactant was determined gravimetrically from the resulting yellowish white powder. The concentration of biosurfactant was determined gravimetrically from the lyophilized powder. The identity of the purified biosurfactant was checked by HPLC.

\subsection{Calculation of fermentation parameters}

To compare the results of the fermentation, the following parameters were determined.

Substrate (glucose) conversion was calculated according to:

$$
\Delta S \%=\frac{S_{0}-S_{\mathrm{f}}}{S_{0}}
$$

where $S_{0}$ and $S_{\mathrm{f}}$ denote the initial substrate and final glucose concentrations, respectively. by:

The biomass yield on glucose $\left(Y_{\frac{x}{S}}, \mathrm{~g} / \mathrm{g}\right)$ was defined

$$
Y_{\frac{x}{s}}=\frac{x_{f}-x_{0}}{S_{0}-S_{f}}
$$

where $x_{\mathrm{f}}$ and $x_{0}$ are the final and initial biomass concentrations, respectively.

The biosurfactant yield on glucose $\left(Y_{\frac{P}{s}}, \mathrm{~g} / \mathrm{g}\right)$ was defined by:

$$
Y_{\frac{P}{s}}=\frac{P_{\mathrm{f}}-P_{0}}{S_{\mathrm{f}}-S_{0}}
$$

where $P_{\mathrm{f}}$ and $P_{0}$ are the final and initial biosurfactant concentrations, respectively.

The volumetric productivities

$$
J_{x}=\frac{x_{\max }}{t_{x_{\max }}}
$$

and

$$
J_{P}=\frac{P_{\max }}{t_{P_{\max }}}
$$

$(\mathrm{g} / \mathrm{l} \cdot \mathrm{h})$ were calculated as the quotients of the maximum biomass concentration $\left(x_{\max }, \mathrm{g} / \mathrm{l}\right)$ or the maximum biosurfactant concentration $\left(P_{\max }, \mathrm{g} / \mathrm{l}\right)$ and the fermentation time $\left(t_{x_{\max }}\right.$ or $\left.t_{P_{\max }}, \mathrm{h}\right)$ when the maximum concentration was achieved, respectively.

\section{Results and Discussion}

To evaluate the effect of $\mathrm{pH}$ on surfactin production, a series of batch fermentations were performed either with or without $\mathrm{pH}$ control. The biosurfactant solution was analysed quantitatively and qualitatively using the HPLC method reported by Mubarak et al. [24].

An overview of the calculated parameters of the batch runs can be seen in Table 1 . In the absence of $\mathrm{pH}$ control, the maximum biomass concentration achieved was $4.00 \mathrm{~g} / \mathrm{L}$ after $35 \mathrm{~h}$ (Fig. 3). Without $\mathrm{pH}$ control, the increased acidity of the medium inhibited further growth at $\mathrm{pH}$ 4.4. The maximum biosurfactant concentration was $4.99 \mathrm{~g} / \mathrm{L}$, which resulted in the surface tension decreasing to $50.1 \mathrm{mN} / \mathrm{m}$. In $\mathrm{pH}$-controlled fermentations, the biomass yields $(0.06$ and $0.08 \mathrm{~g} / \mathrm{g}-\mathrm{pH}$ adjusted with $25 \%$ $\mathrm{NH}_{4} \mathrm{OH}$ and $25 \% \mathrm{NaOH}$ to 7.0 , respectively) were similar to that in the absence of $\mathrm{pH}$ control $(0.06 \mathrm{~g} / \mathrm{g})(\mathrm{Ta}-$ ble 1), while the production of biosurfactants was unable, with a few exceptions, to reduce the surface tension significantly $\left(66.5 \mathrm{mN} / \mathrm{m}\right.$ with $25 \% \mathrm{NH}_{4} \mathrm{OH}$, Table 1; Figs. 4 and 5). This may account for the presence of residual glucose concentrations of 8 to $12 \mathrm{~g} / \mathrm{L}$ (Figs. 4 and 5). The maximum surfactant concentrations were 3.50 and 2.34 $\mathrm{g} / \mathrm{L}$ by adjusting the $\mathrm{pH}$ using $\mathrm{NH}_{4} \mathrm{OH}$ and $\mathrm{NaOH}$, respectively. Although these results are similar to the average yield of surfactants $(3.36 \mathrm{~g} / \mathrm{L})$ in the absence of $\mathrm{pH}$ control, a significant drop in productivity of approxi-

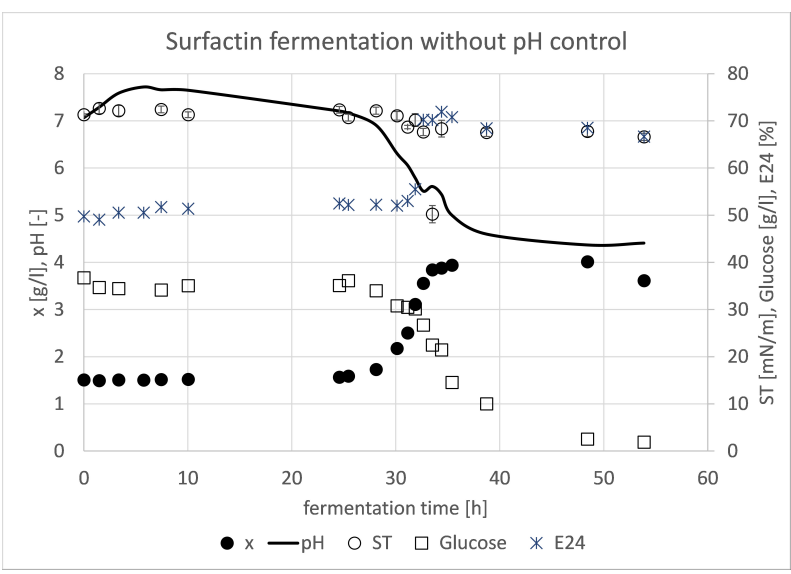

Figure 3: Fermentation of Surfactin - without external pH control 


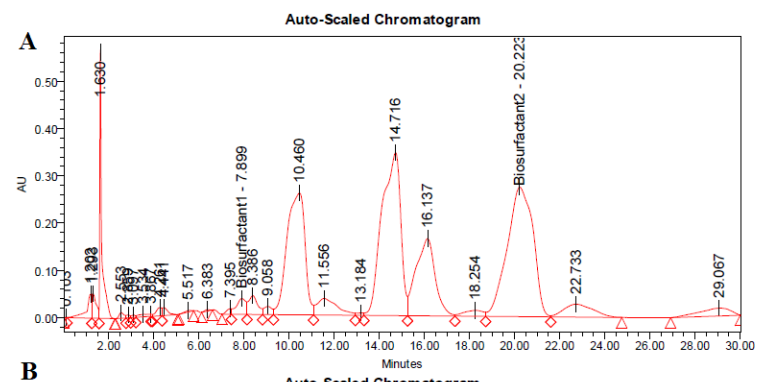

B

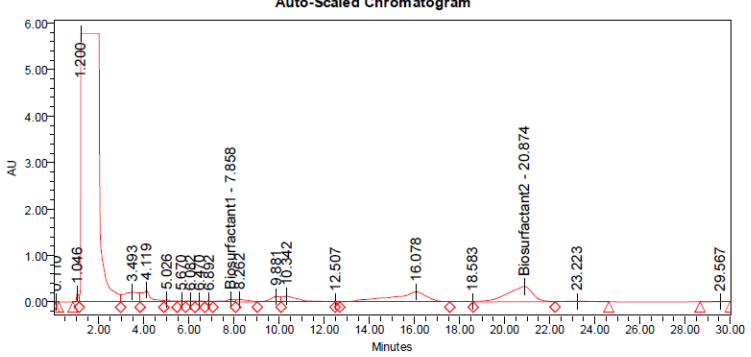

Figure 4: A) HPL chromatogram of a $1.25 \mathrm{~g} / \mathrm{L}$ surfactin standard, B) HPLC chromatogram of the isolated biosurfactant fraction from the foam out sample

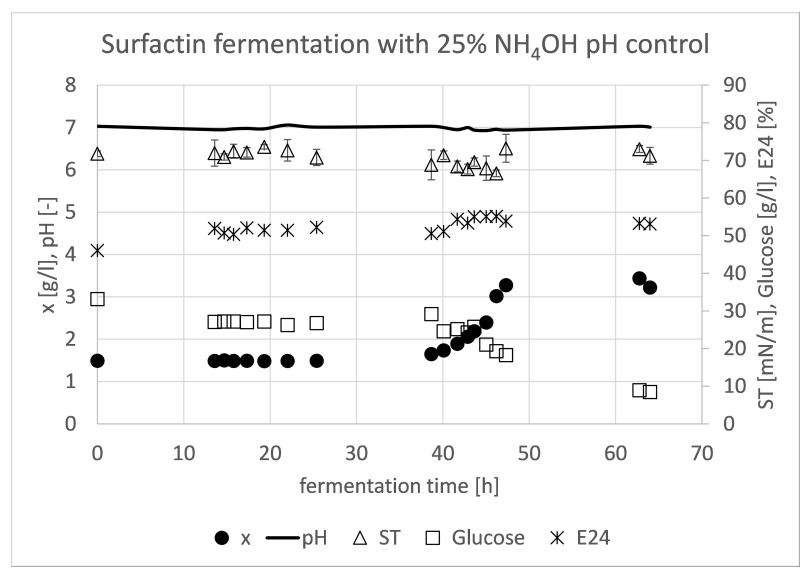

Figure 5: Fermentation of Surfactin - $\mathrm{pH}$ controlled by $25 \% \mathrm{NH}_{4} \mathrm{OH}$.

mately $50 \%$ was observed (Table 1 ).

The highest value of the emulsifying activity $\left(\mathrm{EI}_{24}\right)$ was in excess of $70 \%$ at the end of the exponential phase of the growth curve (at $35 \mathrm{~h}$, Fig. 3). The $\mathrm{EI}_{24}$ values obtained from samples extracted from $\mathrm{pH}$-controlled experiments increased from 45 to $55 \%$ (Figs. 5 and 6, respectively). These inconsistencies can be explained in part by the fact that different Bacillus species and strains are capable of producing numerous surfactin variants with distinct properties. It is highly likely that the production of surfactants is independent of cell growth as $\mathrm{EI}_{24}$ decreased and ST increased during the stationary phase perhaps as a result of degradation by enzymatic hydrolysis or uptake under substrate-limiting conditions [25,26].

Since the spectrum of lipopeptide-type biosurfactants is broad, the profiles of the extracts obtained after the purification process were compared to the surfactin standard. Fig. 4 presents two representative chromatograms:

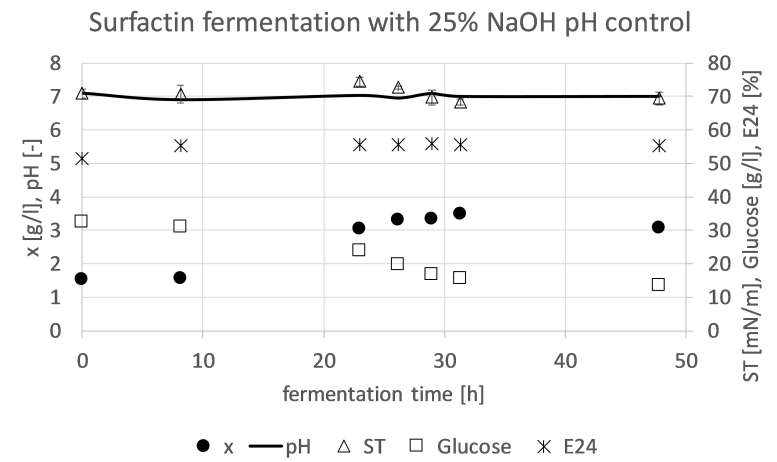

Figure 6: Fermentation of Surfactin - $\mathrm{pH}$ controlled by $25 \% \mathrm{NaOH}$

(A) surfactin standard and (B) purified culture broth of B. subtilis DSM10. Comparatively speaking, the samples from our study exhibited similar peaks (number of peaks, retention time). The intense peak at the beginning of the chromatogram indicates the presence of some nonretained impurities, namely contaminants and inorganic salts such as $\mathrm{NH}_{4} \mathrm{NO}_{3}$, which are often co-extracted with the targeted biosurfactant, that may need to be separated. Overall, based on the separation of peaks and retention time, the isolated biosurfactant was identified as surfactin.

The surfactin titer of B. subtilis DSM10 was compared with the results from relevant studies (Table 2). Even though the fermentation strategies differ to some extent, the surfactin concentration from our work compares well with the values previously reported in the literature.

\section{Conclusion}

The aim of this study was to assess the biosurfactantproducing capability of Bacillus subtilis DSMIO and establish an economically feasible fermentative process. This paper investigated the effect of $\mathrm{pH}$ control on the amount of biosurfactant production. The maximum amount of biosurfactant (approximately $5 \mathrm{~g} / \mathrm{L}$ ) was recovered from fermentation experiments in the absence of $\mathrm{pH}$ control at $37^{\circ} \mathrm{C}$. Furthermore, a preliminary characterization of the surface-active compounds produced during fermentation was conducted. HPLC analysis confirmed the presence of surfactin in the purified product.

Table 2: Surfactin production by Bacillus species

\begin{tabular}{lll}
\hline Strain & Surfactin titer [g/L] & Ref. \\
\hline B. subtilis ATCC 21332 & 6.45 & {$[16]$} \\
B. subtilis & 2.00 & {$[27]$} \\
B. subtilis SPB1 & 4.92 & {$[28]$} \\
B. subtilis DSM10T & 3.99 & {$[29]$} \\
B. subtilis \#573 & 4.80 & {$[6]$} \\
B. subtilis CN2 & 7.15 & {$[30]$} \\
B. subtilis DSM10 & 4.99 & this work \\
\hline
\end{tabular}


The minimum surface tension was $50 \mathrm{mN} / \mathrm{m}$. The emulsifying activity achieved using sunflower oil was approximately $70 \%$. These results represent an initial step towards large-scale production of this biosurfactant. From a technical and economic standpoint, the fermentative process of surfactin carried out in the absence of $\mathrm{pH}$ control in a mineral salt medium using glucose as the sole carbon source seems to be an effective strategy for pilot- and industrial-scale production.

\section{Acknowledgment}

The research was supported by the Gedeon Richter's Talentum Foundation, founded by Gedeon Richter Plc. (Gedeon Richter Ph.D. fellowship). The research reported in this paper has been supported by the $\mathrm{Na}$ tional Research, Development and Innovation Fund TUDFO/51757/2019-ITM, Thematic Excellence Program.

\section{REFERENCES}

[1] Santos, D. K. F.; Rufino, R. D.; Luna, J. M.; Santos, V. A.; Sarubbo, L. A.: Biosurfactants: Multifunctional biomolecules of the 21 st century. Int. J. Mol. Sci. 2016, 17(3), 1-31 DOI: 10.3390/ijms17030401

[2] Satpute, S. K.; Banpurkar, A. G.; Dhakephalkar, P. K.; Banat, I. M.; Chopade, B. A.: Methods for investigating biosurfactants and bioemulsifiers: A review. Crit. Rev. Biotechnol. 2010, 30(2), 127-144 DOI: 10.3109/07388550903427280

[3] Fenibo, E. O.; Douglas, S. I.; Stanley, H. O.: A review on microbial surfactants: Production, classifications, properties and characterization. J. Adv. Microbiol. 2019, 18(3), 1-22 DOI: 10.9734/jamb/2019/v18i330170

[4] Markets and Markets. Natural Surfactants Market (Bio-based Surfactants) https: //www. marketsandmarkets.com/search.asp? search=surfactants

[5] Sajna, K. V.; Höfer, R.; Sukumaran, R. K.; Gottumukkala, L. D.; Pandey, A.: White biotechnology in biosurfactants. in: Industrial biorefineries and white biotechnology; Elsevier B.V., 2015; pp. 499-521 DOI: 10.1016/B978-0-444-63453-5.00016-1

[6] Gudiña, E. J.; Fernandes, E. C.; Rodrigues, A. I.; Teixeira, J. A.; Rodrigues, L. R.: Biosurfactant production by Bacillus subtilis using corn steep liquor as culture medium. Front. Microbiol. 2015, 6, 1-7 DOI: 10.3389/fmicb.2015.00059

[7] Bóka, B.; Manczinger, L.; Kecskeméti, A.; Chandrasekaran, M.; Kadaikunnan, S.; Alharbi, N. S.; Vágvölgyi, Cs.; Szekeres, A.: Ion trap mass spectrometry of surfactins produced by Bacillus subtilis SZMC6179J reveals novel fragmentation features of cyclic lipopeptides. Rapid Commun. Mass Spectrom. 2016, 30(13), 1581-1590 DOI: 10.1002/rcm.7592
[8] From, C.; Hormazabal, V.; Hardy, S. P.; Granum, P. E.: Cytotoxicity in Bacillus mojavensis is abolished following loss of surfactin synthesis: Implications for assessment of toxicity and food poisoning potential. Int. J. Food Microbiol. 2007, 117(1), 43-49 DOI: 10.1016/j.ijfoodmicro.2007.01.013

[9] Moro, G. V.; Almeida, R. T. R.; Napp, A. P.; Porto, C.; Pilau, E. J.; Lüdtke, D. S.; Moro, A. V.; Vainstein, M. H. Identification and ultra-highperformance liquid chromatography coupled with high-resolution mass spectrometry characterization of biosurfactants, including a new surfactin, isolated from oil-contaminated environments. Microb. Biotechnol. 2018, 11(4), 759-769 DOI: 10.1111/17517915.13276

[10] Surfactin - Wikimedia Commons. https: //commons.wikimedia.org/wiki/File: Surfactin.png

[11] De, S.; Malik, S.; Ghosh, A.; Saha, R.; Saha, B.: A review on natural surfactants. $R S C A d v .2015, \mathbf{5}(81)$, 65757-65767 DOI: 10.1039/c5ra11101c

[12] Nitschke, M.; Pastore, G. M.: Production and properties of a surfactant obtained from Bacillus subtilis grown on cassava wastewater. Bioresour. Technol. 2006, 97(2), 336-341 DOI: 10.1016/j.biortech.2005.02.044

[13] Fonseca, R. R.; Silva, A. J. R.; De França, F. P.; Cardoso, V. L.; Sérvulo, E. F. C.: Optimizing carbon/nitrogen ratio for biosurfactant production by a Bacillus subtilis strain. Appl. Biochem. Biotechnol. 2007, 137(1), 471-486 DOI: 10.1007/s12010-007-9073-z

[14] Seydlová, G.; Svobodová, J.: Review of surfactin chemical properties and the potential biomedical applications. Cent. Eur. J. Med. 2008, 3(2), 123-133 DOI: 10.2478/s11536-008-0002-5

[15] Long, X.; He, N.; He, Y.; Jiang, J.; Wu, T.: Biosurfactant surfactin with $\mathrm{pH}$-regulated emulsification activity for efficient oil separation when used as emulsifier. Bioresour. Technol. 2017, 241, 200 206 DOI: 10.1016/j.biortech.2017.05.120

[16] Yeh, M.-S.; Wei, Y.-H.; Chang, J.-S.: Bioreactor design for enhanced carrier-assisted surfactin production with Bacillus subtilis. Process Biochem. 2006, 41(8), 1799-1805 DOI: 10.1016/j.procbio.2006.03.027

[17] Wu, Q.; Zhi, Y.; Xu, Y.: Systematically engineering the biosynthesis of a green biosurfactant surfactin by Bacillus subtilis 168. Metab. Eng. 2019, 52, 8797 DOI: 10.1016/j.ymben.2018.11.004

[18] Akpa, E.; Jacques, P.; Wathelet, B.; Paquot, M.; Fuchs, R.; Budzikiewicz, H.; Thonart, P.: Influence of culture conditions on lipopeptide production by Bacillus subtilis. Appl. Biochem. Biotechnol. - Part A Enzym. Eng. Biotechnol. 2001, 91, 551-561 DOI: 10.1385/ABAB:91-93:1-9:551

[19] Bartal, A.; Vigneshwari, A.; Bóka, B.; Vörös, M.; Takács, I.; Kredics, L.; Manczinger, L.; Varga, M.; Vágvölgyi, Cs.; Szekeres, A.: Effects 
of different cultivation parameters on the production of surfactin variants by a Bacillus subtilis strain. Molecules, 2018, 23(10), 2675 DOI: 10.3390/molecules23102675

[20] Joshi, S. J.; Geetha, S. J.; Yadav, S.; Desai, A. J.: Optimization of bench-scale production of biosurfactant by Bacillus licheniformis R2. APCBEE Procedia 2013, 5, 232-236 DOI: 10.1016/j.apcbee.2013.05.040

[21] Vaz, D. A.; Gudiña, E. J.; Alameda, E. J.; Teixeira, J. A.; Rodrigues, L. R.: Performance of a biosurfactant produced by a Bacillus subtilis strain isolated from crude oil samples as compared to commercial chemical surfactants. Colloids Surf. B: Biointerfaces 2012, 89, 167-174 DOI: 10.1016/j.colsurfb.2011.09.009

[22] Freitas de Oliveira, D. W.; Lima França, Í. W.; Nogueira Félix, A. K.; Lima Martins, J. J.; Aparecida Giro, M. E.; Melo, V. M. M.; Gonçalves, L. R. B.: Kinetic study of biosurfactant production by Bacillus subtilis LAMI005 grown in clarified cashew apple juice. Colloids Surf. B: Biointerfaces 2013, 101, 34-43 DOI: 10.1016/j.colsurfb.2012.06.011

[23] Joshi, S.; Bharucha, C.; Desai, A. J.: Production of biosurfactant and antifungal compound by fermented food isolate Bacillus subtilis $20 \mathrm{~B}$. Bioresour. Technol. 2008, 99(11), 4603-4608 DOI: 10.1016/j.biortech.2007.07.030

[24] Mubarak, M. Q. E.; Hassan, A. R.; Hamid, A. A.; Khalil, S.; Isa, M. H. M.: A simple and effective isocratic HPLC method for fast identification and quantification of surfactin. Sains Malaysiana 2015, 44(1), 115-120 DOI: 10.17576/jsm-2015-4401-16
[25] Mukherjee, S.; Das, P.; Sivapathasekaran, C.; Sen, R.: Antimicrobial biosurfactants from marine Bacillus circulans: Extracellular synthesis and purification. Lett. Appl. Microbiol. 2009, 48(3), 281-288 DOI: 10.1111/j.1472-765X.2008.02485.x

[26] Rodríguez, N.; Salgado, J. M.; Cortés, S.; Domínguez, J. M.: Alternatives for biosurfactants and bacteriocins extraction from Lactococcus lactis cultures produced under different $\mathrm{pH}$ conditions. Lett. Appl. Microbiol. 2010, 51(2), 226-233 DOI: 10.1111/j.1472-765X.2010.02882.x

[27] Amani, H.; Mehrnia, M. R.; Sarrafzadeh, M. H.; Haghighi, M.; Soudi, M. R.: Scale up and application of biosurfactant from Bacillus subtilis in enhanced oil recovery. Appl. Biochem. Biotechnol. 2010, 162(2), 510-523 DOI: 10.1007/s12010-009-8889-0

[28] Ghribi, D.; Ellouze-Chaabouni, S.: Enhancement of Bacillus subtilis lipopeptide biosurfactants production through optimization of medium composition and adequate control of aeration. Biotechnol. Res. Int. 2011, 1-6 DOI: 10.4061/2011/653654

[29] Willenbacher, J.; Rau, J. T.; Rogalla, J.; Syldatk, C.; Hausmann, R.: Foam-free production of surfactin via anaerobic fermentation of Bacillus subtilis DSM $10^{\mathrm{T}}$. AMB Express 2015, 5(1) DOI: 10.1186/s13568-0150107-6

[30] Bezza, F. A.; Chirwa, E. M. N.: Production and applications of lipopeptide biosurfactant for bioremediation and oil recovery by Bacillus subtilis CN2. Biochem. Eng. J. 2015, 101, 168-178 DOI: 10.1016/j.bej.2015.05.007 